\title{
Classic and Non-Classic Effects of the Duration of Supplementation of 25-Hydroxicholecalciferol in Broiler Chicken Diets
}

\author{
Karen Prokoski ${ }^{1}$, Leticia C. Bittencourt ${ }^{2}$, Levy V. Teixeira ${ }^{2, *}$, Cristiano Bortoluzzi ${ }^{2}$, Elisangela Vanroo ${ }^{1}$, \\ Sabrina Palma ${ }^{1}$ and Jovanir I. M. Fernandes ${ }^{1}$
}

check for

updates

Citation: Prokoski, K.; Bittencourt, L.C.; Teixeira, L.V.; Bortoluzzi, C.; Vanroo, E.; Palma, S.; Fernandes, J.I.M. Classic and Non-Classic Effects of the Duration of Supplementation of 25-Hydroxicholecalciferol in Broiler Chicken Diets. Animals 2021, 11, 2971. https://doi.org/10.3390/ani11102971

Academic Editors: María Cambra-López and Juan José Pascual

Received: 23 September 2021

Accepted: 13 October 2021

Published: 15 October 2021

Publisher's Note: MDPI stays neutral with regard to jurisdictional claims in published maps and institutional affiliations.

Copyright: (c) 2021 by the authors. Licensee MDPI, Basel, Switzerland. This article is an open access article distributed under the terms and conditions of the Creative Commons Attribution (CC BY) license (https:// creativecommons.org/licenses/by/ $4.0 /)$.
1 Laboratory of Poultry Experimentation, Federal University of Parana, Palotina 85950-000, Brazil; karenprokoski@yahoo.com.br (K.P.); elizangela.vanroo@gmail.com (E.V.); sabrina.castro@ufpr.br (S.P.); jimfernandes@ufpr.br (J.I.M.F.)

2 DSM Nutritional Products, Sao Paulo 18120-000, Brazil; leticia.cardoso@dsm.com (L.C.B.); cristiano.bortoluzzi@dsm.com (C.B.)

* Correspondence: levy.teixeira@dsm.com

Simple Summary: Genetic programs of modern commercial-type broiler chickens are based on growth performance parameters associated with muscular growth, feed efficiency, and meat and breast yield. Therefore, highly bioavailable vitamin $\mathrm{D}_{3}$ to sustain optimal muscle and bone development is necessary. In the present study the effect of different durations of supplementing of 25-hydroxycholecalciferol $\left(25(\mathrm{OH}) \mathrm{D}_{3}\right)$ in broiler chickens was evaluated. Growth performance response, carcass and cuts yield, bone resistance, plasma concentration of $25(\mathrm{OH}) \mathrm{D}_{3}$, and expression of the mTOR gene were evaluated. The use of $25(\mathrm{OH}) \mathrm{D}_{3}$ in the diets for broilers during different feeding periods did not influence growth performance but increased the plasma concentration of $25(\mathrm{OH}) \mathrm{D}_{3}$, and increased breast yield as the duration of the supplementation was extended. The supplementation of $25(\mathrm{OH}) \mathrm{D}_{3}$ increased breast yield and protein deposition in the breast muscle which may have been a result of the epigenetic changes caused by this vitamin D (Vit D) metabolite.

Abstract: The present study aimed to determine the effect of different times of supplementation of 25-hydroxycholecalciferol $\left(25(\mathrm{OH}) \mathrm{D}_{3}\right)$ in broiler chickens on the performance, carcass and cuts yield, bone resistance, plasma concentration of $25(\mathrm{OH}) \mathrm{D}_{3}$, and expression of the mTOR gene. The treatments were a control diet (CD) supplemented with $3000 \mathrm{IU}$ vitamin $\mathrm{D}_{3} / \mathrm{kg}$ of feed from 1 to $46 \mathrm{~d}$, or the $\mathrm{CD}+2760 \mathrm{IU}$ (69 mcg) of $25(\mathrm{OH}) \mathrm{D}_{3} / \mathrm{kg}$ of feed from 1 to $21 \mathrm{~d}$, from 1 to $35 \mathrm{~d}$, or from 1 to $46 \mathrm{~d}$. The period of supplementation of $25(\mathrm{OH}) \mathrm{D}_{3}$ did not affect the growth performance of broilers, but the breast meat yield was linearly increased in response to increasing days of supplementation $(p<0.05)$. Birds supplemented with $25(\mathrm{OH}) \mathrm{D}_{3}$ at the time of the analysis showed an increase $(p<0.05)$ in the plasma concentration of $25(\mathrm{OH}) \mathrm{D}_{3}$ when compared to non-supplemented birds. The mTOR gene expression $(p<0.05)$, and breast protein deposition $(p<0.05)$ presented a quadratic response related to the supplementation period of $25(\mathrm{OH}) \mathrm{D}_{3}$. The fat content of the breast linearly decreased $(p<0.05)$ as the period of supplementation was extended. The results also showed a positive linear correlation between mTOR expression and $25(\mathrm{OH}) \mathrm{D}_{3}$ plasma levels $(\mathrm{r}=0.593 ; p<0.05)$.

Keywords: broiler; breast yield; mTOR; $25(\mathrm{OH}) \mathrm{D}_{3}$

\section{Introduction}

The Brazilian poultry industry has shown significant growth in the last few decades mainly to meet the internal demand, and to support the high exporting rates observed in the past years [1]. The genetic programs of modern commercial-type broiler chickens are based on growth performance parameters associated mainly with an elevated muscular growth, feed efficiency, and meat and breast yield. However, this high growth rate may 
increase the needs for more bioavailable nutrients and for higher absorption rates to sustain optimal muscle and bone development, which otherwise would result in the appearance of locomotor problems.

With the objective of reducing losses related to the locomotor system, research has focused on nutritional alternatives to mitigate such problems. Work on vitamin D and its metabolites has been a subject of major interest when studying nutritional-skeletal abnormality interactions [2]. Vitamin $\mathrm{D}_{3}$ and its metabolites are of paramount importance to maintain the homeostasis of calcium $(\mathrm{Ca})$ and phosphorus $(\mathrm{P})$ by regulating their intestinal uptake, renal excretion, and bone structure, functions that are classically described in the literature $[2,3]$. However, vitamin $\mathrm{D}_{3}$ is not metabolically active, being necessary to go through two steps of hydroxylation. The first hydroxylation renders $25-\mathrm{Hydroxycholecalciferol}\left(25(\mathrm{OH}) \mathrm{D}_{3}\right)$ which is the main metabolite found in the plasma and constitute an important storage of the vitamin. The second hydroxylation results in the production of 1,25-dihydroxycholecalciferol, the biologically active form of vitamin D [3]. Different metabolites of vitamin $\mathrm{D}\left(\mathrm{D}_{3}, 25(\mathrm{OH}) \mathrm{D}_{3}, 1,25\left(\mathrm{OH}_{2}\right) \mathrm{D}_{3}\right)$ are available for animal nutrition, with the objective to supply a more active form of the vitamin, to reduce the energetic expenditure of its metabolism, and to obtain better outcomes, such as performance and meat yield [4-7].

Several studies have demonstrated that $25(\mathrm{OH}) \mathrm{D}_{3}$ has higher metabolic activity and is a more efficient source of vitamin $\mathrm{D}$ in diets of broilers when compared to vitamin $\mathrm{D}_{3}$. It has been reported that the absorption of $25(\mathrm{OH}) \mathrm{D}_{3}$ is $83 \%$ faster compared to vitamin $\mathrm{D}_{3}$ in broilers [8]. This higher absorption rate may be related to the fact that $25(\mathrm{OH}) \mathrm{D}_{3}$ has higher affinity (at least 1000-fold) to intestinal receptors than other vitamin D metabolites [9]. Several studies in poultry have shown a better growth performance and overall bone health when $25(\mathrm{OH}) \mathrm{D}_{3}$ was included in the diet $[5-7,10]$. It was observed that $25(\mathrm{OH}) \mathrm{D}_{3}$ supplementation was twice as effective as vitamin $\mathrm{D}_{3}$ in promoting weight gain and bone resistance in broilers [6] and that it increased bone resistance by $36 \%$ in $21-\mathrm{d}$-old chickens [11] and tended to increase mineral density of femur and tibia in laying hens at late stages of production ( $>57$ weeks) [7] or under height stocking density [12].

These results highlight the classic effects of $25(\mathrm{OH}) \mathrm{D}_{3}$ in improving performance and bone quality in poultry. There are questions as to whether the duration of supplementation would influence its non-classical effects in broilers that remain to be answered. To our knowledge, no studies have evaluated times of supplementation of $25(\mathrm{OH}) \mathrm{D}_{3}$ in broilers and incorporated the non-classical effects (expression of mTOR gene, carcass yield, and deposition of fat and protein in the breast muscle) in parallel with the classical effects (growth performance and bone quality). Epigenetic changes of genes related to the metabolism and deposition of proteins could explain, in part, the better breast yield observed in birds supplemented with $25(\mathrm{OH}) \mathrm{D}_{3}$ [13]. It was demonstrated that $25(\mathrm{OH}) \mathrm{D}_{3}$ increased its plasma concentration and protein synthesis in the breast muscle 3-fold and upregulated the protein expression of mTOR [13]. The mTOR pathway controls protein synthesis by phosphorylating translational regulators, which in turn enhances mRNA biogenesis [14]. Nevertheless, $25(\mathrm{OH}) \mathrm{D}_{3}$ supplementation improve different aspects of the intestinal physiology, immunology, and microbiology in broilers [11,15-17].

Therefore, we hypothesized that a longer period of supplementation of the $25(\mathrm{OH}) \mathrm{D}_{3}$ metabolite would maintain its plasma concentration and upregulate the expression of the mTOR gene in the breast muscle, which would be translated into improved growth performance, carcass yield, and bone resistance in broiler chickens. The objective of the present study was to evaluate different durations of supplementation of $25(\mathrm{OH}) \mathrm{D}_{3}$ metabolite (Hy-D) in broiler chickens on the performance, carcass and cuts yield, tibia resistance, breast protein deposition and fat content, plasma concentration of $25(\mathrm{OH}) \mathrm{D}_{3}$, and expression of the mTOR gene. 


\section{Materials and Methods}

\subsection{Birds, House, and Treatments}

A total of 1584 one-day-old RossAP95 male broiler chickens were divided into a completely randomized design with four treatments and nine replicate pens of 44 birds each replicate (each replicate pen had similar initial body weight, with $\pm 5 \%$ ). Vitamin $\mathrm{D}$ was supplied in equal concentrations (3000 IU $/ \mathrm{kg}$ of feed) as vitamin $\mathrm{D}_{3}$ in all the diets. The experiment consisted of four treatments-the control diet (CD) supplemented with $3000 \mathrm{IU}$ vitamin $\mathrm{D}_{3} / \mathrm{kg}$ from 1 to $46 \mathrm{~d}$, and three additional treatments that consisted of different times of supplementation of $25(\mathrm{OH}) \mathrm{D}_{3} / \mathrm{kg}$ of feed, as follows: $\mathrm{CD}+2760 \mathrm{IU}$ $(69 \mathrm{mcg})$ of $25(\mathrm{OH}) \mathrm{D}_{3} / \mathrm{kg}$ of feed from 1 to $21 \mathrm{~d}$, from 1 to $35 \mathrm{~d}$, or from 1 to $46 \mathrm{~d}$. When the supplemental period of $25(\mathrm{OH}) \mathrm{D}_{3}$ ended, the broilers returned to the control diet (Table 1), except when the supplementation lasted from 1 to $46 \mathrm{~d}$ of age.

The diets were based on corn and soybean meal and formulated following the chemical composition of feedstuffs and nutritional recommendations adopted by the regional poultry industry (Palotina, Paraná, Brazil; Table 2). The feeding program was divided into three phases-starter (1 to $21 \mathrm{~d}$ ), grower (1 to $35 \mathrm{~d}$ ), and finisher (1 to $46 \mathrm{~d}$ ). The concentration of vitamin D used in the experimental diets were based on the DSM Vitamin Supplementation guidelines (DSM ROVIMIX Hy-D; DSM Nutritional Products, Basel, Switzerland) for broiler chickens (DSM, 2011). The vitamin D metabolite, $25(\mathrm{OH}) \mathrm{D}_{3}$, was included in the vitamin and mineral premix according to the treatment and feeding phase, and its concentration in the diets has been determined and is presented in Table 2 .

The birds were vaccinated at the hatchery against Marek's disease, infectious bursal disease, and infectious bronchitis, and placed into floor pens with re-used litter (4th rearing flock). The temperature in the experimental poultry house was maintained by the use of electric heaters, exhausters, and pad cooling according to each phase of the chickens. The birds received $24 \mathrm{~h}$ of light from d 0 to 14 , and $16 \mathrm{~h}$ of light and $8 \mathrm{~h}$ of dark afterwards. The litter management (revolving) was done on $\mathrm{d} 14$ and 28. Water and feed (mash form) were supplied ad libitum throughout the study.

Table 1. Experimental treatments.

\begin{tabular}{ccccc}
\hline Treatments & $\begin{array}{c}\text { Vitamin D } \\
\text { (IU/kg) }\end{array}$ & $\begin{array}{c}\mathbf{2 5}_{\mathbf{O}} \mathbf{O H} \mathbf{D}_{\mathbf{3}} \mathbf{1} \\
\mathbf{( I U / k g )}\end{array}$ & $\begin{array}{c}\text { Total Vitamin D } \\
\text { Activity }\end{array}$ & $\begin{array}{c}\text { Period } \\
\text { (Days) }\end{array}$ \\
\hline T1 & 3000 & - & 3000 & $0-46$ \\
\hline \multirow{2}{*}{ T2 } & 3000 & 2760 & 5760 & $0-21$ \\
& 3000 & - & 3000 & $22-46$ \\
\hline \multirow{2}{*}{ T3 } & 3000 & 2760 & 5760 & $0-35$ \\
& 3000 & - & 3000 & $36-46$ \\
\hline T4 & 3000 & 2760 & 5760 & $0-46$ \\
\hline
\end{tabular}

${ }^{1} 25(\mathrm{OH}) \mathrm{D}_{3}$ was included in the vitamin and mineral premix according to the treatment and feeding phase, and its concentration in the diets has been determined and is presented in Table 2. ( $1 \mathrm{mcg}=40 \mathrm{IU})$.

Table 2. Nutritional composition of the experimental diets.

\begin{tabular}{cccc}
\hline Ingredients, $\%$ & Starter & Grower & Finisher \\
\hline Corn $7.5 \%$ & 60.17 & 63.85 & 69.06 \\
Soybean meal 46.7\% & 30.90 & 26.80 & 22.30 \\
Meat bone meal 48.5\% & 4.500 & 3.600 & 2.900 \\
Soybean oil & 2.100 & 3.500 & 3.600 \\
Limestone & 0.580 & 0.560 & 0.560 \\
Salt & 0.200 & 0.190 & 0.200 \\
Sodium bicarbonate & 0.290 & 0.270 & 0.240 \\
\hline
\end{tabular}


Table 2. Cont.

\begin{tabular}{|c|c|c|c|}
\hline Ingredients, $\%$ & Starter & Grower & Finisher \\
\hline Vitamin and mineral premix ${ }^{1}$ & 0.300 & 0.300 & 0.300 \\
\hline Choline $60 \%$ & 0.096 & 0.074 & 0.060 \\
\hline DL-Methionine $98 \%$ & 0.369 & 0.352 & 0.320 \\
\hline L-Lysine 50.7\% & 0.292 & 0.320 & 0.322 \\
\hline L-Threonine $98 \%$ & 0.099 & 0.100 & 0.082 \\
\hline L-Valine $96.5 \%$ & 0.046 & 0.071 & 0.060 \\
\hline Salinomycin $12 \%$ & - & 0.055 & - \\
\hline Nicarbazin + Narasin $80 / 80$ & 0.05 & - & - \\
\hline \multicolumn{4}{|l|}{$\begin{array}{l}\text { Calculated nutritional } \\
\text { composition }\end{array}$} \\
\hline $\mathrm{CP}, \%$ & 22.00 & 20.00 & 18.00 \\
\hline $\mathrm{ME}, \mathrm{Kcal} / \mathrm{kg}$ & 3050 & 3180 & 3250 \\
\hline Fat, \% & 5.233 & 6.555 & 6.698 \\
\hline $\mathrm{CF}, \%$ & 2.359 & 2.210 & 2.061 \\
\hline Calcium, \% & 0.950 & 0.840 & 0.760 \\
\hline AvP, \% & 0.470 & 0.420 & 0.380 \\
\hline Dig. Lys., \% & 1.256 & 1.160 & 1.040 \\
\hline Dig. AAS, $\%$ & 0.967 & 0.906 & 0.832 \\
\hline Dig. Thr, \% & 0.829 & 0.767 & 0.687 \\
\hline Dig. Trp, \% & 0.229 & 0.205 & 0.179 \\
\hline Dig. Val, \% & 0.954 & 0.894 & 0.801 \\
\hline $\mathrm{Na}, \%$ & 0.200 & 0.190 & 0.180 \\
\hline $\mathrm{Cl}, \%$ & 0.240 & 0.240 & 0.240 \\
\hline Analyzed $25(\mathrm{OH}) \mathrm{D}_{3}, \mathrm{mcg}^{2}$ & 67.9 & 63.4 & 63.6 \\
\hline
\end{tabular}

CP: crude protein; ME: metabolizable energy; CF: crude fiber; AvP: available phosphorus. ${ }^{1}$ Starter feed (provided per kg of feed): Vit A: 12,000 IU; Vit $\mathrm{D}_{3}: 3000 \mathrm{IU}$; Vit E: 70 mg; Vit K3: 4.50 mg; Vit B1: 2.6 mg; Vit B2: 7.5 mg; Vit B6: $4.5 \mathrm{mg}$; Vit B12: $0.025 \mathrm{mg}$; niacin: $50 \mathrm{mg}$; pantothenic acid: $19 \mathrm{mg}$; folic acid: $1.9 \mathrm{mg}$; biotin: $0.18 \mathrm{mg}$; Se: $0.3 \mathrm{mg}$; Fe: $0.3 \mathrm{~g}$; Cu: $0.06 \mathrm{~g}$; Mn: $0.39 \mathrm{~g}$; Zn: $0.39 \mathrm{mg}$; I: $0.006 \mathrm{mg}$; phytase: $1000 \mathrm{FYT}$; Rovimix HyD (25(OH)D $)$ $2760 \mathrm{IU}(69 \mathrm{mcg})$. Grower feed (provided per kg of feed): Vit A: $9000 \mathrm{IU} ; \mathrm{Vit}_{3}: 3000 \mathrm{IU}$; Vit E: $50 \mathrm{mg}$; Vit K3: $3.75 \mathrm{mg}$; Vit B1: $2.1 \mathrm{mg}$; Vit B2: $6 \mathrm{mg}$; Vit B6: $3.5 \mathrm{mg}$; Vit B12: $0.02 \mathrm{mg}$; niacin: $40 \mathrm{mg}$; pantothenic acid: $15 \mathrm{mg}$; folic acid: $1.5 \mathrm{mg}$; biotin: $0.15 \mathrm{mg}$; Se: $0.3 \mathrm{mg}$; Fe: $0.3 \mathrm{~g}$; Cu: $0.06 \mathrm{~g}$; Mn: $0.39 \mathrm{~g}$; Zn: $0.39 \mathrm{mg}$; I: $0.006 \mathrm{mg}$; phytase: 1000 FYT; Rovimix HyD (25(OH)D $\left.\mathrm{D}_{3}\right): 2760 \mathrm{IU}(69 \mathrm{mcg})$. Finisher feed (provided per $\mathrm{kg}$ of feed): Vit A: $7000 \mathrm{IU}$; Vit $\mathrm{D}_{3}$ : $3000 \mathrm{IU}$; Vit E: $35 \mathrm{mg}$; Vit K3: $2.75 \mathrm{mg}$; Vit B1: $1.75 \mathrm{mg}$; Vit B2: $5 \mathrm{mg}$; Vit B6: $2.5 \mathrm{mg}$; Vit B12: $0.015 \mathrm{mg}$; niacin: $30 \mathrm{mg}$; pantothenic acid: $11 \mathrm{mg}$; folic acid: $1.1 \mathrm{mg}$; biotin: $0.10 \mathrm{mg}$; Se: $0.3 \mathrm{mg}$; Fe: $0.3 \mathrm{~g}$; $\mathrm{Cu}: 0.06 \mathrm{~g}$; $\mathrm{Mn}$ : $0.39 \mathrm{~g}$; Zn: $0.39 \mathrm{mg}$; I: $0.006 \mathrm{mg}$; phytase: $1000 \mathrm{FYT}$; Rovimix HyD (25(OH) $\left.\mathrm{D}_{3}\right): 2760 \mathrm{IU}$ (69 mcg). ${ }^{2}$ Analyzed at the DSM Laboratory (Basel, Switzerland), following Schadt et al. [18].

\subsection{Growth Performance and Carcass Yield}

The birds and feed were weighed on 7, 21,35, and $46 \mathrm{~d}$ of age to calculate body weight gain (BWG), feed intake (FI), and feed conversion ratio (FCR). The FCR was corrected by the weekly mortality according to Sakomura and Rostagno [19].

On d 46, 12 birds per pen (108 birds/treatment) were randomly selected to determine carcass and cuts yield. After fasting for six hours, the birds were desensitized by electroshock, slaughtered by bleeding through the jugular vein, scalded, plucked, and eviscerated. To calculate the carcass yield, the weight of the hot eviscerated carcass without feet, head, and abdominal fat was expressed relative to the live weight. The cuts yield (whole breast with skin and bones, legs with bones and skin, back and wings with skin) was determined relative to the weight of the hot eviscerated carcass. The whole breast of each bird was deboned to determine the total breast meat, skinless and boneless filet and sassami yields. Wing, medallion, cartilage, and abdominal fat (fat around cloaca, bursa, gizzard, proventriculus, and abdominal muscles) were determined relative to the hot eviscerated carcass.

\subsection{Plasma Concentration of $25(\mathrm{OH}) \mathrm{D}_{3}$}

Plasma concentration of $25(\mathrm{OH}) \mathrm{D}_{3}$ was determined on $\mathrm{d} 21,35$ and 46 from two birds per experimental unit (18 birds/treatment). The blood samples, obtained by venipunc- 
ture from the brachial vein, were placed into anticoagulant test tubes and immediately centrifuged at $9000 \mathrm{rpm}$ for $60 \mathrm{~s}$; the plasma was stored at $-80^{\circ} \mathrm{C}$. Plasma concentration of $25(\mathrm{OH}) \mathrm{D}_{3}$ was performed by liquid chromatography coupled to mass spectrometry (LC-MS), according to the methodology described by Weber et al. [20].

\subsection{Protein Deposition and Fat Content in the Breast Muscle}

The deposition of protein in the breast muscle was determined on day $4624 \mathrm{~h}$ after slaughter from six birds per pen (54 birds/treatment), the same birds that were used for the carcass yield analysis. The right pectoralis major muscle (breast filet) was individually ground using a meat grinder (ECCEL-MCIE98), and after homogenization smaller samples were dried under $55^{\circ} \mathrm{C}$ for $72 \mathrm{~h}$. After drying, the samples were ground in a knife mill, and the protein analysis was performed by the Kjeldahl method, through acid digestion, followed by distillation and titration.

The fat content was determined by histologic evaluation. For this, samples of the pectoralis major muscle were collected ( 54 birds per treatment), fixed and paraffin embedded. The slices were longitudinally oriented, eight microns thick and submitted to Masson's trichrome staining (EP-11-20013 code, Easypath, Erviegas Surgical, Inc, São Paulo, Brazil). The images were captured using a high-resolution Media Cibertecnics PRO SERIES digital camera, coupled to an Olympus Bx 40 microscope, $4 \times$ magnification. A computerized IMAGE PROPLUS 5.2 image analyzer (Cibertecnics Media) was used to read the images to measure the content of fat intermingling the muscle bundles in relation to the total area of the captured cut. For such, a color was assigned to the measured structure in order to establish the contrast between the collagen, protein, and fat. The percentage of fat was calculated based on the difference between the total area captured and the percentage of collagen and protein.

\subsection{Tibia Breaking Strength Analysis}

For the analysis of tibia resistance, 54 tibias per treatment from the birds used to evaluate protein and fat content analyses were used. After removal of all adherent tissues of the leg of each bird, the bones were submitted to integrity evaluation. The tibia was weighed, and the length and diameter were measured using a digital paquimeter ( $\mathrm{mm})$. The Seedor index [21] was obtained by dividing the bone weight ( $\mathrm{mg}$ ) by its length (mm). The tibia was also submitted to the flexural test (bone strength at break) at a rate of constant deformation for viscoelastic material with PMPA equipment (Stable Micro Systems Physical and Mechanical Properties Analysis System) with cell load of $500 \mathrm{kgf}$, and head speed of $10 \mathrm{~mm} / \mathrm{s}$.

\section{6. $m R N A$ Expression of the mTOR Gene in the Breast Muscle}

The mRNA expression of the mTOR gene was analyzed by real-time PCR. The samples of breast muscle (six per treatment) were collected from the cranial portion of the breast, frozen into liquid nitrogen, and sent for the mTOR gene expression analysis. Briefly, the total mRNA was extracted using the Trizol reagent (Invitrogen, Carlsbad, CA, USA). The RNA pellet was dissolved in RNase-free ultrapure water. The total concentration, quality, and integrity of the mRNA were determined using a spectrophotometer (NanoDrop ND 1000, NanoDrop Technologies, Wilmington, DE, USA). For the cDNA preparation, the SuperScripptTM III First-Strand Synthesis Super Mix and Oligo d(T) kit (Invitrogen Corporation, Carlsbad, CA, USA), and RNAse out (Invitrogen Corporation, Carlsbad, CA, USA) were used for mRNA degradation according to the manufacturer's instructions. The real-time PCR reactions were performed by using the SYBR GREEN fluorescent dye method (SYBR GREEN PCR Master Mix, Applied Biosystems, Foster, CA, USA). Real-time PCR analyses were performed on the Bio-Rad iQ5 ${ }^{\mathrm{TM}}$ thermal cycler (Bio-Rad Laboratories, Hercules, CA, USA) using the following cycle parameters: $95^{\circ} \mathrm{C}$ for $10 \mathrm{~min}, 40$ cycles of denaturation at $95^{\circ} \mathrm{C}$ for $15 \mathrm{~s}$, annealing at $60^{\circ} \mathrm{C}$ for $1 \mathrm{~min}$, and melting curve at $95^{\circ} \mathrm{C}$ to evaluate the specificity. 
The mTOR primer sequences were, forward-TTGGGTTTGCTTTCTGTGGCTGTC, and reverse-ACAGACTTCTGCCTCTTGTGAGCA (Accession number XM_417614.2; $119 \mathrm{bp}$ ) [22]. The relative standard-curve method was used to quantify the mRNA concentrations of the mTOR gene in relation to the reference gene $(\beta$-actin-forward GCCAACAGAGAGAAGATGAC, and reverse-CACCAGAGTCCATCACAATAC). The mRNA relative abundance was calculated according to the method of Livak and Schmittgen [23].

\subsection{Statistical Analysis}

The data were checked for outliers and then subjected to analysis of normality of studentized errors and homogeneity of variances. Pen and bird were considered as the experimental unit for growth performance and remaining analyses, respectively. Based on these assumptions, ANOVA was performed by using the statistical program SAS 9.0. The means showing significance $(p \leq 0.05)$ and trending $(0.05<p \leq 0.10)$ treatment differences in the ANOVA were compared by Tukey's test. Polynomial regression (PROC REG) as a function of the period of $25(\mathrm{OH}) \mathrm{D}_{3}$ supplementation, and Pearson correlation analysis (PROC CORR) between the expression of mTOR and plasma concentration of $25(\mathrm{OH}) \mathrm{D}_{3}$ were also performed using SAS $9.0(p \leq 0.05)$.

\section{Results}

\subsection{Growth Performance and Carcass and Cuts Yield}

The growth performance results from 1 to 7,1 to 21,1 to 35 , and 1 to $46 \mathrm{~d}$ are shown in Table 3. No effect $(p>0.05)$ of the dietary supplementation of $25(\mathrm{OH}) \mathrm{D}_{3}$ on the BWG, FI, or FCR was observed in any of the phases evaluated.

The results of carcass yield and cuts are presented in the Table 4 . Birds fed diets supplemented with $25(\mathrm{OH}) \mathrm{D}_{3}$ from 1 to $46 \mathrm{~d}$ had a higher carcass $(p<0.05)$ and breast $(p<0.05)$ yield when compared to birds fed the same diet from 1 to $35 \mathrm{~d}$ or from 1 to $21 \mathrm{~d}$, respectively. Additionally, in the regression analysis, an effect $(p<0.05)$ was observed for breast yield as a function of the $25(\mathrm{OH}) \mathrm{D}_{3}$ supplementation period (Table 4$)$. The breast yield was linearly increased $(p<0.05 ; \hat{Y}=0.0131 x+29.802$; Figure 1$)$ by the supplementation period of $25(\mathrm{OH}) \mathrm{D}_{3}$, i.e., the longer the birds received of the $25(\mathrm{OH}) \mathrm{D}_{3}$ in diet, the higher was the breast yield. The other carcass traits were not influenced $(p>0.05)$ by the supplementation period of $25(\mathrm{OH}) \mathrm{D}_{3}$.

Table 3. Productive performance of broiler chickens supplemented with vitamin $\mathrm{D}_{3}$ from 1 to $46 \mathrm{~d}$ or vitamin $\mathrm{D}_{3}$ plus $25(\mathrm{OH}) \mathrm{D}_{3}$ from 0 to 21,0 to 35 , or 0 to 46 days of age.

\begin{tabular}{|c|c|c|c|}
\hline Treatment & BWG, $\mathrm{g}$ & FI, $\mathrm{g}$ & FCR \\
\hline \multicolumn{4}{|c|}{0 to $7 \mathrm{~d}$} \\
\hline Control $^{1}$ & 134.1 & 161.8 & 1.208 \\
\hline $25(\mathrm{OH}) \mathrm{D}_{3}$ & 134.8 & 161.4 & 1.202 \\
\hline $\mathrm{CV}, \%$ & 4.51 & 3.55 & 6.28 \\
\hline$p$ value & 0.75 & 0.86 & 0.80 \\
\hline \multicolumn{4}{|c|}{0 to $21 \mathrm{~d}$} \\
\hline Control $^{1}$ & 975 & 1288 & 1.322 \\
\hline $25(\mathrm{OH}) \mathrm{D}_{3}$ & 979 & 1284 & 1.312 \\
\hline $\mathrm{CV}, \%$ & 2.53 & 2.48 & 2.36 \\
\hline$p$ value & 0.63 & 0.80 & 0.47 \\
\hline \multicolumn{4}{|c|}{0 to $35 \mathrm{~d}$} \\
\hline Control $^{1}$ & 2395 & 3461 & 1.446 \\
\hline $25(\mathrm{OH}) \mathrm{D}_{3} 1-21 \mathrm{~d}^{2}$ & 2384 & 3446 & 1.446 \\
\hline $25(\mathrm{OH}) \mathrm{D}_{3} 1-35 \mathrm{~d}^{3}$ & 2390 & 3409 & 1.427 \\
\hline $\mathrm{CV}, \%$ & 3.65 & 3.28 & 1.62 \\
\hline$p$ value & 0.96 & 0.48 & 0.21 \\
\hline
\end{tabular}


Table 3. Cont.

\begin{tabular}{cccc}
\hline Treatment & BWG, $\mathbf{g}$ & FI, g & FCR \\
\hline \multicolumn{3}{c}{0 to $46 \mathrm{~d}$} \\
\hline Control $^{1}$ & 3340 & 5365 & 1.606 \\
$25(\mathrm{OH}) \mathrm{D}_{3} 1-21 \mathrm{~d}^{2}$ & 3314 & 5300 & 1.602 \\
$25(\mathrm{OH}) \mathrm{D}_{3} 1-35 \mathrm{~d}^{3}$ & 3360 & 5283 & 1.574 \\
$25(\mathrm{OH}) \mathrm{D}_{3} 1-46 \mathrm{~d}^{4}$ & 3264 & 5186 & 1.590 \\
$\mathrm{CV}, \%$ & 6.23 & 5.75 & 2.68 \\
$p$ value & 0.79 & 0.66 & 0.45 \\
Regression & $\mathrm{Ns}$ & $\mathrm{Ns}$ & $\mathrm{Ns}$ \\
\hline
\end{tabular}

BWG: body weight gain; FI: feed intake; FCR: feed conversion ratio; ${ }^{1}$ control diet (CD): 3000 IU vitamin $\mathrm{D}_{3} ;{ }^{2} \mathrm{CD}+2760 \mathrm{IU} / \mathrm{kg} 25(\mathrm{OH}) \mathrm{D}_{3}$ fed from 0 to 21 days; ${ }^{3} \mathrm{CD}+2760 \mathrm{IU} / \mathrm{kg} 25(\mathrm{OH}) \mathrm{D}_{3}$ fed from 0 to 35 days ${ }^{4} \mathrm{CD}+2760 \mathrm{IU} / \mathrm{kg} 25(\mathrm{OH}) \mathrm{D}_{3}$ from 0 to 46 days; $\mathrm{CV}$ : coefficient of variation; Ns: not significant. ( $n=9$ pens/treatment; $p<0.05$ ).

Table 4. Carcass and cuts yield, and abdominal fat deposition of broiler chickens supplemented with vitamin $\mathrm{D}_{3}$ from 1 to $46 \mathrm{~d}$ or vitamin $\mathrm{D}_{3}$ plus $25(\mathrm{OH}) \mathrm{D}_{3}$ from 0 to 21,0 to 35 , or 0 to 46 days of age.

\begin{tabular}{|c|c|c|c|c|c|c|c|}
\hline \multirow{2}{*}{ Characteristics } & Control $^{1}$ & $25(\mathrm{OH}) \mathrm{D}_{3}{ }^{2}$ & $25(\mathrm{OH}) \mathrm{D}_{3}{ }^{3}$ & $25(\mathrm{OH}) \mathrm{D}_{3}^{4}$ & $C V, \%$ & $p$ Value & Regression \\
\hline & & 1 to 21 Days & 1 to 35 Days & 1 to 46 Days & & & \\
\hline Carcass, \% & $80.6^{a, b}$ & $80.7^{a, b}$ & $80.2^{b}$ & $81.1^{\mathrm{a}}$ & 2.8 & 0.04 & Ns \\
\hline Breast (filet + sassami), $\%$ & $29.9^{a, b}$ & $29.7^{b}$ & $30.2^{a, b}$ & $30.5^{\mathrm{a}}$ & 6.6 & 0.04 & Linear \\
\hline Filet, $\%$ & 24.7 & 24.7 & 25.1 & 25.2 & 7.1 & 0.08 & Ns \\
\hline Sassami, \% & 5.2 & 5.1 & 5.1 & 5.2 & 10.2 & 0.07 & Ns \\
\hline Legs, \% & 31.6 & 31.7 & 31.1 & 31.3 & 6.2 & 0.09 & Ns \\
\hline Wings, \% & 9.9 & 9.7 & 9.6 & 9.6 & 10.3 & 0.17 & Ns \\
\hline Back, \% & 22.3 & 22.3 & 22.2 & 21.9 & 7.1 & 0.38 & Ns \\
\hline Medallion, \% & 1.9 & 1.9 & 1.9 & 1.9 & 14.7 & 0.54 & Ns \\
\hline Skin, \% & 2.3 & 2.3 & 2.3 & 2.3 & 16.8 & 0.76 & Ns \\
\hline Breast flaps, $\%$ & 0.7 & 0.7 & 0.7 & 0.7 & 35.6 & 0.97 & Ns \\
\hline Fat, $\%$ & 0.9 & 1.9 & 1.9 & 1.8 & 34.8 & 0.71 & Ns \\
\hline Breast cartilage, $\%$ & 0.3 & 0.3 & 0.3 & 0.3 & 26.6 & 0.53 & Ns \\
\hline
\end{tabular}

${ }^{1}$ Control diet (CD): $3000 \mathrm{IU}$ vitamin $\mathrm{D}_{3} ;{ }^{2} \mathrm{CD}+2760 \mathrm{IU} / \mathrm{kg} 25(\mathrm{OH}) \mathrm{D}_{3}$ fed from 0 to 21 days; ${ }^{3} \mathrm{CD}+2760 \mathrm{IU} / \mathrm{kg} 25(\mathrm{OH}) \mathrm{D}_{3}$ fed from 0 to 35 days; ${ }^{4} \mathrm{CD}+2760 \mathrm{IU} / \mathrm{kg} 25(\mathrm{OH}) \mathrm{D}_{3}$ from 0 to 46 days; $\mathrm{CV}$ : coefficient of variation; Ns: not significant. ${ }^{\mathrm{a}, \mathrm{b}}$ Means followed by different letters in the same row differ from each $(n=108$ birds/treatment; $p<0.05)$.

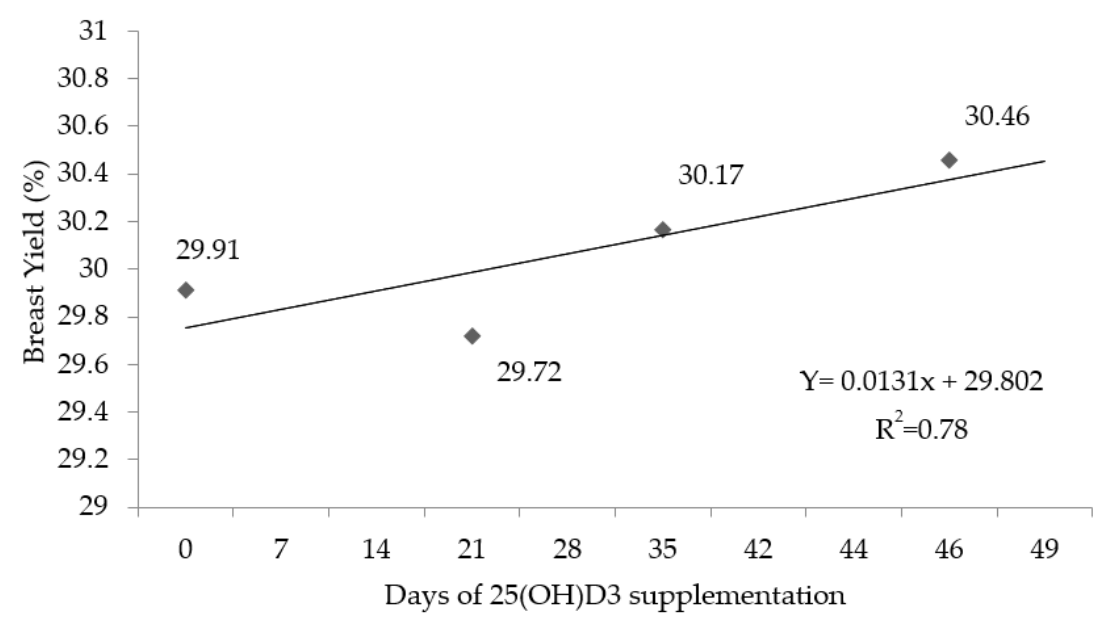

Figure 1. Breast yield (filet + sassami) broiler chickens at $46 \mathrm{~d}$ supplemented with vitamin $\mathrm{D}_{3}$ from 1 to $46 \mathrm{~d}$ or vitamin $\mathrm{D}_{3}$ plus $25(\mathrm{OH}) \mathrm{D}_{3}$ from 0 to 21,0 to 35 , or 0 to 46 days of age. ( $n=108$ birds $/$ treatment; $p<0.05$ ). 


\subsection{Plasma Concentration of $25(\mathrm{OH}) \mathrm{D}_{3}$}

The dietary treatments affected $(p<0.05)$ the plasma concentration of $25(\mathrm{OH}) \mathrm{D}_{3}$ in the different periods evaluated (Figure 2). Birds supplemented with $25(\mathrm{OH}) \mathrm{D}_{3}$ at the time of the analysis showed an increase of its concentration in the plasma when compared to the non-supplemented birds. It was observed that the maintenance of higher plasma concentration of $25(\mathrm{OH}) \mathrm{D}_{3}$ was dependent on its dietary supplementation in association with vitamin $D_{3}$. The vitamin $D_{3}$ supplementation alone was not able to maintain the plasma concentration of $25(\mathrm{OH}) \mathrm{D}_{3}$ after the removal of $25(\mathrm{OH}) \mathrm{D}_{3}$ metabolite from the diet.
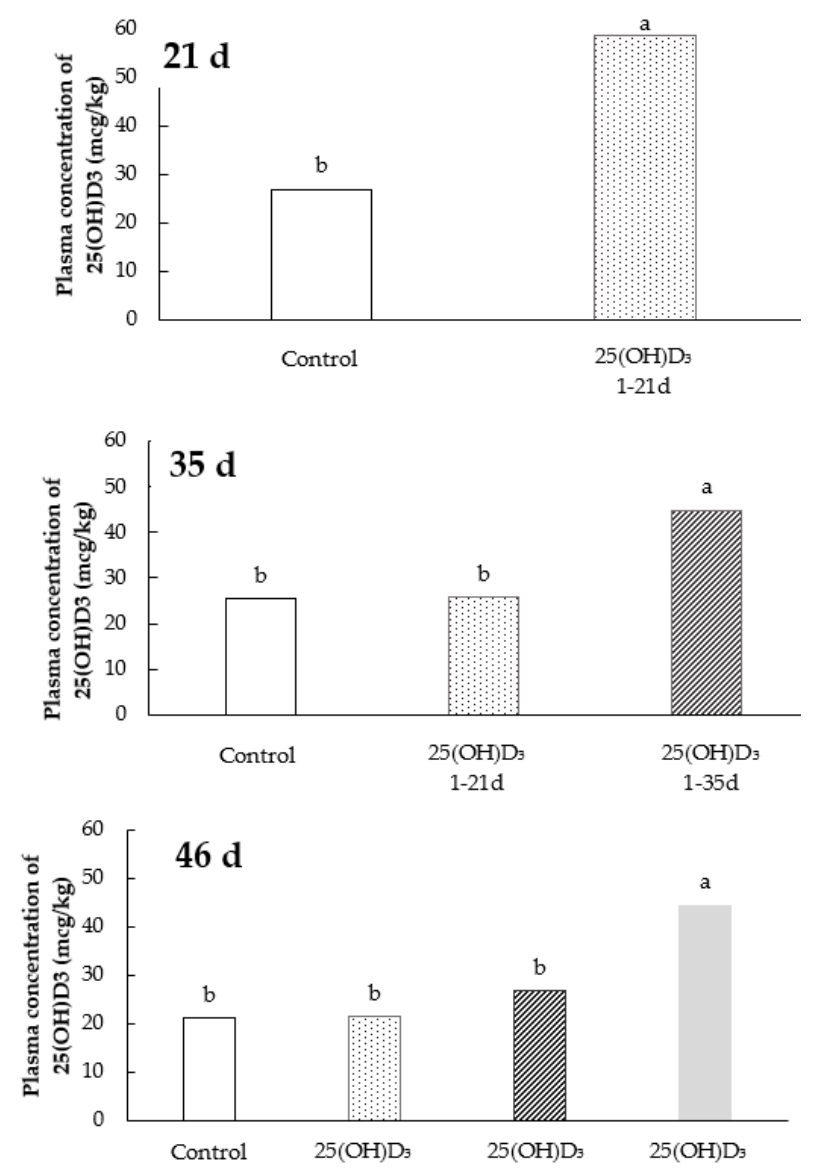

Figure 2. Plasma concentration of $25(\mathrm{OH}) \mathrm{D}_{3}$ of broiler chickens at 21,35 , and $46 \mathrm{~d}$ supplemented

with vitamin $\mathrm{D}_{3}$ from 0 to $46 \mathrm{~d}$ or vitamin $\mathrm{D}_{3}$ plus $25(\mathrm{OH}) \mathrm{D}_{3}$ from 0 to 21,0 to 35 , or 0 to 46 days of age. Data are presented as mean $\pm \operatorname{SEM}(n=18$ /group). Bars with different letters show significant difference between groups ( $n=18$ birds/treatment; $p<0.05)$.

\subsection{Protein Deposition and Fat Content in the Breast Muscle}

The results of the protein deposition and fat content in the breast muscle are shown in Figure 3. A quadratic effect was observed $\left(p<0.05 ; \hat{Y}=0.0031 x^{2}-0.1154 x+81.888\right)$ on the protein deposition according to the period of $25(\mathrm{OH}) \mathrm{D}_{3}$ supplementation, wherein the highest deposition of protein was verified in birds that received $25(\mathrm{OH}) \mathrm{D}_{3}$ supplementation during the entire experimental period ( 1 to $46 \mathrm{~d}$ ). For the fat content, it was observed a linear effect $(p<0.05 ; \hat{Y}=-0.0137 x+2.9858)$, in which the fat content of the breast was reduced as the period of supplementation lasted longer. 

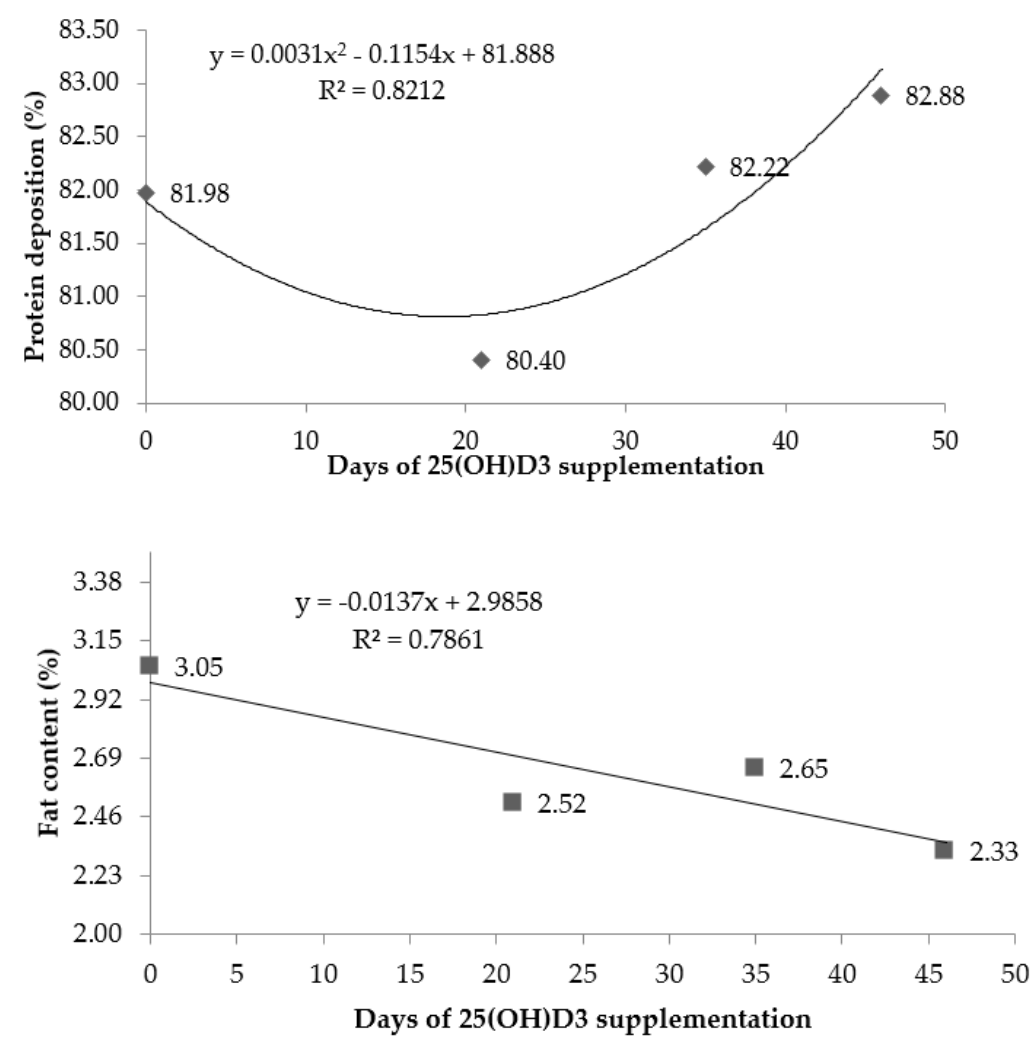

Figure 3. Protein and fat content in the breast muscle of broiler chickens at $46 \mathrm{~d}$ supplemented with vitamin $\mathrm{D}_{3}$ from 0 to $46 \mathrm{~d}$ or vitamin $\mathrm{D}_{3}$ plus $25(\mathrm{OH}) \mathrm{D}_{3}$ from 0 to 21,0 to 35 , or 0 to 46 days of age. ( $n=54$ birds/treatment).

\subsection{Tibia Breaking Strength Analysis}

The results of the tibia resistance analysis of broilers performed at $46 \mathrm{~d}$ are shown in Table 5. There was a trend $(p=0.09)$ towards increased resistance of the tibia in birds that received the dietary supplementation of $25(\mathrm{OH}) \mathrm{D}_{3}$ when compared to the control group of birds, regardless of the duration of supplementation. In addition, a trend $(p=0.09)$ towards higher tibia length was observed in broilers supplemented with $25(\mathrm{OH}) \mathrm{D}_{3}$ from 1 to $35 \mathrm{~d}$.

Table 5. Resistance and measurements of tibia at $46 \mathrm{~d}$ of broiler chickens supplemented with vitamin $\mathrm{D}_{3}$ from 0 to $46 \mathrm{~d}$ or vitamin $\mathrm{D}_{3}$ plus $25(\mathrm{OH}) \mathrm{D}_{3}$ from 0 to 21,0 to 35 , or 0 to 46 days of age.

\begin{tabular}{|c|c|c|c|c|c|c|c|}
\hline & Control $^{1}$ & $25(\mathrm{OH}) \mathrm{D}_{3}{ }^{2}$ & $25(\mathrm{OH}) \mathrm{D}_{3}{ }^{3}$ & $25(\mathrm{OH}) \mathrm{D}_{3}^{4}$ & \multirow{2}{*}{$C V, \%$} & \multirow{2}{*}{$p$ Value } & \multirow{2}{*}{ Regression } \\
\hline & & 1 to $21 \mathrm{~d}$ & 1 to $35 \mathrm{~d}$ & 1 to $46 \mathrm{~d}$ & & & \\
\hline Resistance, kg & 43.8 & 48.3 & 47.6 & 47.0 & 19.0 & 0.09 & Ns \\
\hline Weight, g & 33.0 & 33.4 & 32.7 & 32.5 & 12.4 & 0.74 & Ns \\
\hline Diameter, mm & 15.8 & 16.0 & 15.7 & 16.0 & 9.8 & 0.85 & Ns \\
\hline Length, mm & 121.7 & 119.7 & 122.3 & 120.8 & 4.7 & 0.09 & Ns \\
\hline Seedor Index & 271.3 & 279.04 & 267.9 & 269.1 & 11.8 & 0.29 & Ns \\
\hline
\end{tabular}

${ }^{1}$ Control diet (CD): $3000 \mathrm{IU}$ vitamin $\mathrm{D}_{3} ;{ }^{2} \mathrm{CD}+2760 \mathrm{IU} / \mathrm{kg} 25(\mathrm{OH}) \mathrm{D}_{3}$ fed from 0 to 21 days; ${ }^{3} \mathrm{CD}+2760 \mathrm{IU} / \mathrm{kg} 25(\mathrm{OH}) \mathrm{D}_{3}$ fed from 0 to 35 days; ${ }^{4} \mathrm{CD}+2760 \mathrm{IU} / \mathrm{kg} 25(\mathrm{OH}) \mathrm{D}_{3}$ from 0 to 46 days; CV: coefficient of variation; Ns: not significant. $(n=54$ birds/treatment; $p<0.05)$.

\section{5. mRNA Expression of the mTOR Gene in the Breast Muscle}

The results of mRNA expression of the mTOR gene in the breast muscle performed at $\mathrm{d} 46$, and its correlation with the plasma concentration of $25(\mathrm{OH}) \mathrm{D}_{3}$ are shown in Figure 4. A quadratic increase $(p<0.05)$ in mTOR expression was observed as a function of the timing of $25(\mathrm{OH}) \mathrm{D}_{3}$ supplementation, with the higher expression being observed in birds that received $25(\mathrm{OH}) \mathrm{D}_{3}$ from 1 to $46 \mathrm{~d}$ of age. Additionally, there was a positive correlation 
$(\mathrm{r}=0.58, p=0.004)$ between the gene expression of mTOR and the plasma concentration of $25(\mathrm{OH}) \mathrm{D}_{3}$.
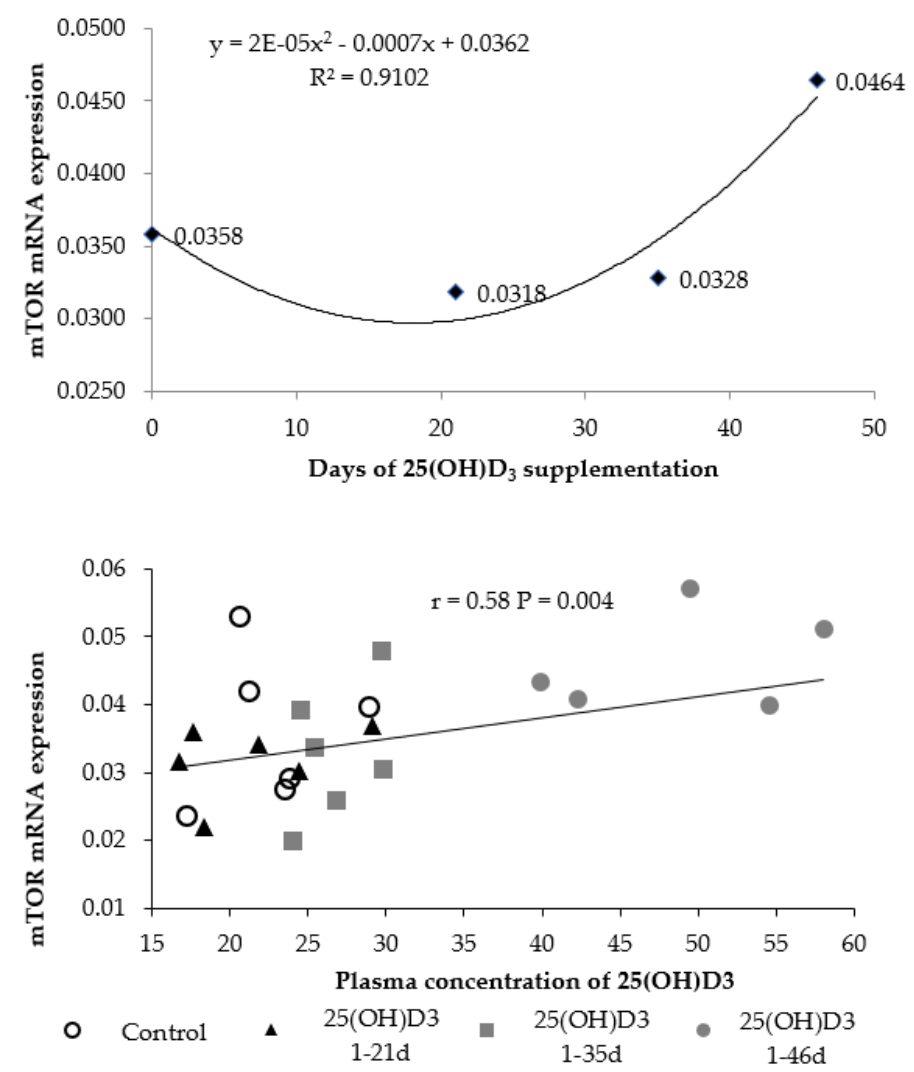

Figure 4. mRNA expression $\left(2^{-\Delta \Delta C}\right.$ ) of mTOR protein synthesis initiator gene in the breast muscle and correlation between its expression and the plasma concentration $25(\mathrm{OH}) \mathrm{D}_{3}$ of broiler chickens at $46 \mathrm{~d}$ supplemented with vitamin $\mathrm{D}_{3}$ from 0 to $46 \mathrm{~d}$ or vitamin $\mathrm{D}_{3}$ plus $25(\mathrm{OH}) \mathrm{D}_{3}$ from 0 to 21,0 to 35 , or 0 to 46 days of age. ( $n=6$ birds/treatment for mTOR gene expression and $n=18$ birds $/$ treatment for plasma concentration of $\left.25(\mathrm{OH}) \mathrm{D}_{3}\right)$.

\section{Discussion}

In the present study we evaluated the classical (growth performance, bone resistance, and plasma $25(\mathrm{OH}) \mathrm{D}_{3}$ concentration) and non-classical (carcass and cuts yield, fat and protein deposition in the breast, and mTOR gene expression) effects of the $25(\mathrm{OH}) \mathrm{D}_{3}$ dietary supplementation in broilers during different periods of supplementation ( 1 to $21 \mathrm{~d}$, 1 to $35 \mathrm{~d}$, and 1 to $46 \mathrm{~d})$. When the supplemental period of $25(\mathrm{OH}) \mathrm{D}_{3}$ ended, the broilers returned to the control diet (Table 1), except when the supplementation lasted from 1 to $46 \mathrm{~d}$ of age. We hypothesized that the supplementation of $25(\mathrm{OH}) \mathrm{D}_{3}$ throughout the complete production cycle of broiler chickens, would maintain the blood concentration of 25(OH)D3 and upregulate the expression of the mTOR gene in the breast muscle, which would be translated into improved growth performance and carcass characteristics. Overall, the supplementation of $25(\mathrm{OH}) \mathrm{D}_{3}$ did not influence growth performance; however, the breast yield was linearly increased by the duration of supplementation, and the tibia resistance tended to increase. The lack of significant result on the tibia resistance may be due to the effect of $25(\mathrm{OH}) \mathrm{D}_{3}$ on bone development being more evident around day 21 [11,24], with an enhanced muscle development later in life [13,25].

Supplementing different metabolites in association with a source of vitamin $\mathrm{D}_{3}$ is a method of maximizing animal performance since it reduces the energy expenditure with the vitamin $\mathrm{D}$ metabolism. It may be possible that if the vitamin $\mathrm{D}_{3}$ concentration of the basal diet of the current study was lower, the effects of the addition of $25(\mathrm{OH}) \mathrm{D}_{3}$ would have been more pronounced. Moreover, the lack of an immunological stress that would 
impair the absorption of nutrients, and therefore, the growth performance may explain the absence of significant differences between treatments. Additionally, the adequate levels of nutrients present in the basal diet, mainly $\mathrm{Ca}$ and $\mathrm{P}$, may influence the results since the efficacy of vitamin D and its metabolites is dependent upon the availability of nutrients [26,27], or presence of intestinal infection. Indeed, Oikeh et al. [16] showed that coccidiosis infection reduces the plasma concentration of $25(\mathrm{OH}) \mathrm{D}_{3}$ at least up to 12 days after the infection. Therefore, due to the constant intestinal challenges faced by the poultry industry more bioactive sources of vitamin D supplemented throughout the life of the birds may be necessary to maximize the intestinal absorption, as observed by Leyva-Jimenez et al. [11].

Similar results to those observed in this study were reported before when evaluating $25(\mathrm{OH}) \mathrm{D}_{3}$ for broilers during growth and finisher phases without significant improvement in productive performance [16,28-31]. However, improved performance with $25(\mathrm{OH}) \mathrm{D}_{3}$ supplementation was reported by Fritts and Waldroup [32], wherein $125 \mathrm{IU} / \mathrm{kg}$ of $25(\mathrm{OH}) \mathrm{D}_{3}$ enhanced the $\mathrm{BWG}$ on $\mathrm{d} 42$ to the same level and birds receiving $1000 \mathrm{IU} / \mathrm{kg}$ of vitamin $\mathrm{D}_{3}$, leading to the conclusion that lower concentrations of vitamin $\mathrm{D}$ from $25(\mathrm{OH}) \mathrm{D}_{3}$ may be used with greater margin of safety. Furthermore, Sakkas et al. [31] reassessed the effect of higher dietary concentration of vitamin $\mathrm{D}_{3}$ and the partial replacement of $\mathrm{D}_{3}$ by $25(\mathrm{OH}) \mathrm{D}_{3}$ in Ross broilers. There was an improved femur and tibia mineralization when $3000 \mathrm{IU} / \mathrm{kg}$ of $25(\mathrm{OH}) \mathrm{D}_{3}$ was added to the diet, even though no differences in performance were observed, which partially agrees with our results. Interestingly, the partial substitution of vitamin $\mathrm{D}_{3}$ by $25(\mathrm{OH}) \mathrm{D}_{3}$ increased the serum concentration of $25(\mathrm{OH}) \mathrm{D}_{3}$ only on d 11 and 25 but not on d 39 [31]. On the other hand, Leyva-Jimenez et al. [11] reported that the replacement of $50 \%$ of vitamin $\mathrm{D}_{3}$ by $25(\mathrm{OH}) \mathrm{D}_{3}$ increased body weight, tibia breaking strength, and plasma concentration of $25(\mathrm{OH}) \mathrm{D}_{3}$ on $\mathrm{d} 21$ (7 days after a coccidiosis vaccine challenge), compared to vitamin- $\mathrm{D}_{3}$-only fed birds.

The elevated $25(\mathrm{OH}) \mathrm{D}_{3}$ concentration in the plasma obtained in the present study indicates that its dietary supplementation can increase vitamin $\mathrm{D}$ status in broilers. Indeed, we reported an increase of plasma $25(\mathrm{OH}) \mathrm{D}_{3}$ by $54.1 \%, 42.3 \%$ and $52.4 \%$ on $\mathrm{d} 21,35$, and 46 , respectively, when compared to unsupplemented birds. Similar results have been reported before with higher plasma concentration of $25(\mathrm{OH}) \mathrm{D}_{3}$ ranging from 22 to $63 \%$ when the partial dietary replacement was adopted $[16,25,31]$, with broader increase being observed in younger birds, and by $126 \%$ with total replacement of vitamin $\mathrm{D} 3$ by $25(\mathrm{OH}) \mathrm{D}_{3}$ [13] The findings of the present study demonstrated that the longer the dietary supplementation of $25(\mathrm{OH}) \mathrm{D}_{3}$ the higher was its plasma concentration. This finding must be emphasized because the breast yield linearly increased as a function of the time of supplementation, most likely due to the higher availability of plasma $25(\mathrm{OH}) \mathrm{D}_{3}$ to sustain muscle growth. According to Ovesen et al. [33], in humans, about $80 \%$ of the circulating activity of vitamin $\mathrm{D}$ is in the form of $25(\mathrm{OH}) \mathrm{D}_{3}$. Similarly, in chicks, $25(\mathrm{OH}) \mathrm{D}_{3}$ is the major metabolite of vitamin $\mathrm{D}$ in the blood [34]. The absorption of $25(\mathrm{OH}) \mathrm{D}_{3}$ has been reported to be more efficient than vitamin $\mathrm{D}_{3}$ in the small intestine [8]. The faster absorption can be attributed to the biding capacity of $25(\mathrm{OH}) \mathrm{D}_{3}$ to proteins in the intestinal cells [35], that have about a 1000 -fold greater affinity to $25(\mathrm{OH}) \mathrm{D}_{3}$ than to other metabolites of vitamin $\mathrm{D}$ [35].

Evidence on the mechanisms by which $25(\mathrm{OH}) \mathrm{D}_{3}$ influences muscle hypertrophic growth, composition, and fiber size has been reported [13,25,30]. Hutton et al. [25] observed that feeding broiler chickens with $25(\mathrm{OH}) \mathrm{D}_{3}$ increased the status of vitamin $\mathrm{D}$ in the birds and increased the number of mitotically active satellite cells in the breast muscle, supporting the fact that the proliferation of muscle fiber and satellite cells is stimulated by circulating levels of $25(\mathrm{OH}) \mathrm{D}_{3}$ [25]. Even though the exact mechanism of this response is yet to be elucidated, an increase in the muscle development with the supplementation of $25(\mathrm{OH}) \mathrm{D}_{3}$ is expected. In the present study, at $d 46$, an increase of $1.11 \%$ in the carcass yield and $2.62 \%$ in the breast yield (filet + sassami) was observed in birds supplemented with $25(\mathrm{OH}) \mathrm{D}_{3}$ from 1 to $46 \mathrm{~d}$, compared to those supplemented from 1 to 35 or 1 to $21 \mathrm{~d}$, respectively. These results agree with Vignale et al. [13] wherein the supplementation of $25(\mathrm{OH}) \mathrm{D}_{3}$ from 
1 to $42 \mathrm{~d}$, but not from 1 to $21 \mathrm{~d}$, increased breast yield. The increase in breast yield without changing feed intake and body weight observed in this study indicates that $25(\mathrm{OH}) \mathrm{D}_{3}$ can affect energy use as reported by Vignale et al. [13]. Interestingly, besides increasing protein deposition, the time of supplementation of $25(\mathrm{OH}) \mathrm{D}_{3}$ linearly reduced the fat content in the breast tissue likely due to the potent effect of $25(\mathrm{OH}) \mathrm{D}_{3}$ on muscle gene expression which may indirectly reduce the fat deposition in different tissues, another non-classical effect of this metabolite [36].

Improvement of vitamin D status in metabolism results in changes in muscle activity [14]. In order to define the mechanism by which $25(\mathrm{OH}) \mathrm{D}_{3}$ benefits muscle growth in broilers, we also evaluated the mTOR signaling pathway. The mTOR pathway is largely involved in the regulation of protein synthesis [37] and regulates growth and homeostasis of an organism [14]. Vignale et al. [13] showed that the use of dietary $25(\mathrm{OH}) \mathrm{D}_{3}$ enhanced breast meat production and led to a 3-fold increase of fractional protein synthesis rate compared to birds supplemented with vitamin $\mathrm{D}_{3}$. Molecular analyses revealed that the breast muscle development of chickens fed $25(\mathrm{OH}) \mathrm{D}_{3}$ for $42 \mathrm{~d}$ is probably mediated by the mTOR-S6K pathway. In the current study, the supplementation of $25(\mathrm{OH}) \mathrm{D}_{3}$ throughout the life of the birds upregulated the expression of mTOR in the breast muscle as measured on $\mathrm{d} 46$. Additionally, the correlation analysis showed that the expression of this gene was positively correlated with plasma $25(\mathrm{OH}) \mathrm{D}_{3}$, which helps to explain the observed higher breast yield and protein deposition in the breast muscle.

\section{Conclusions}

In conclusion, the use of $25(\mathrm{OH}) \mathrm{D}_{3}$ in the diets for broilers during different feeding periods did not influence growth performance but increased the plasma concentration of $25(\mathrm{OH}) \mathrm{D}_{3}$ as the duration of supplementation was extended, and linearly increased breast yield as a function of the timing of supplementation. The supplementation of $25(\mathrm{OH}) \mathrm{D}_{3}$ increased breast yield and protein deposition and reduced the fat content in the breast muscle which may be a result of the upregulation of the mTOR gene.

Author Contributions: Conceptualization, J.I.M.F., L.V.T. and L.C.B.; methodology, K.P., E.V. and S.P.; writing—original draft preparation, K.P. and C.B.; writing-review and editing, C.B., J.I.M.F., L.V.T. and L.C.B. All authors have read and agreed to the published version of the manuscript.

Funding: This research was funded by DSM Nutritional Products.

Institutional Review Board Statement: The experiment was conducted at the Laboratory of Poultry Experimentation of the Federal University of Paraná-Palotina, PR, Brazil. All the experimental procedures were approved by the institutional Animal Care and Use Committee (protocol number 51/2014).

Informed Consent Statement: Not applicable.

Data Availability Statement: Not applicable.

Conflicts of Interest: The authors declare no conflict of interest.

\section{References}

1. ABPA. Brazilian Association of Animal Protein. Annual Report. 2020. Available online: www.abpa.com.br (accessed on 2 June 2020).

2. Edwards, H.M. Nutrition and Skeletal Problems in Poultry. Poult. Sci. 2000, 79, 1018-1023. [CrossRef]

3. McDowell, L.R. (Ed.) Vitamin D. In Vitamin in Animal Nutrition; Academic Press: Gainesville, FL, USA, 1989 ; pp. 55-92.

4. Garcia, A.F.Q.M.; Murakami, A.E.; do Duarte, C.R.A.; Rojas, I.C.O.; Picoli, K.P.; Puzotti, M.M. Use of Vitamin D3 and Its Metabolites in Broiler Chicken Feed on Performance, Bone Parameters and Meat Quality. Asian-Australas. J. Anim. Sci. 2013, 26, 408-415. [CrossRef]

5. Morris, A.; Shanmugasundaram, R.; McDonald, J.; Selvaraj, R.K. Effect of in vitro and in vivo 25-hydroxyvitamin D treatment on macrophages, T cells, and layer chickens during a coccidia challenge. J. Anim. Sci. 2016, 93, 2894-2903. [CrossRef] [PubMed]

6. Han, J.C.; Chen, G.H.; Wang, J.G.; Zhang, J.L.; Qu, H.X.; Zhang, C.M.; Yan, Y.F.; Cheng, Y.H. Evaluation of Relative Bioavailability of 25-Hydroxycholecalciferol to Cholecalciferol for Broiler Chickens. Asian-Australas. J. Anim. Sci. 2016, 29, 1145-1151. [CrossRef] 
7. Adhikari, R.; White, D.; House, J.D.; Kim, W.K. Effects of additional dosage of vitamin D3, vitamin D2, and 25-hydroxyvitamin D3 on calcium and phosphorus utilization, egg quality and bone mineralization in laying hens. Poult. Sci. 2020, 99, 364-373. [CrossRef] [PubMed]

8. Bar, A.; Sharvit, M.; Noff, D.; Edelstein, S.; Hurwitz, S. Absorption and excretion of cholecalciferol and of 25-hydroxycholecalciferol and metabolites in birds. J. Nutr. 1980, 110, 1930-1934. [CrossRef] [PubMed]

9. Teegarden, D.; Meredith, S.C.; Sitrin, M.D. Isolation and characterization of a 25-hydroxyvitamin D binding protein from rat enterocyte cytosol. J. Nutr. Biochem. 1997, 8, 195-200. [CrossRef]

10. Bello, A.; Hester, P.Y.; Gerard, P.D.; Zhai, W.; Peebles, E.D. Effects of commercial in ovo injection of 25-hydroxycholecalciferol on bone development and mineralization in male and female broilers. Poult. Sci. 2014, 93, 2734-2739. [CrossRef] [PubMed]

11. Levya-Jimenez, H.; Gardner, K.; AL-Jumaa, Y.; Padgett, J.C.; Bailey, C.A. Partial replacement of dietary cholecalciferol with 25-hydroxycholecalciferol on broiler chickens subjected to a coccidiosis vaccine challenge. J. Appl. Poul. Res. 2019, 28, 743-754. [CrossRef]

12. Wang, J.; Qiu, L.; Gong, H.; Celi, P.; Yan, L.; Ding, X.; Bai, S.; Zeng, Q.; Mao, X.; Xu, S.; et al. Effect of dietary 25hydroxycholecalciferol supplementation and high stocking density on performance, egg quality, and tibia quality in laying hens. Poult. Sci. 2019, 99, 2608-2615. [CrossRef]

13. Vignale, K.; Greene, E.S.; Caldas, J.V.; England, J.A.; Boonsinchai, N.; Sodsee, P.; Pollock, E.D.; Dridi, S.; Coon, C.N. 25Hydroxycholecalciferol Enhances Male Broiler Breast Meat Yield through the mTOR Pathway. J. Nutr. 2015, 145, 855-863. [CrossRef]

14. Ma, X.M.; Blenis, J. Molecular mechanisms of mTOR-mediated translational control. Nat. Rev. Mol. Cell Biol. 2009, 10, 307-318. [CrossRef]

15. Chou, S.H.; Chung, T.K.; Yu, B. Effects of supplemental 25-hydroxycholecalciferol on growth performance, small intestinal morphology, and immune response of broiler chickens. Poult. Sci. 2009, 88, 2333-2341. [CrossRef] [PubMed]

16. Oikeh, I.; Sakkas, P.; Blake, D.P.; Kyriazakis, I. Interactions between dietary calcium and phosphorus level, and vitamin D source on bone mineralization, performance, and intestinal morphology of coccidia-infected broilers. Poult. Sci. 2019, 98, 5679-5690. [CrossRef] [PubMed]

17. Zeng, Y.; Luo, M.; Pan, L.; Chen, Y.; Guo, S.; Luo, D.; Zhu, L.; Liu, Y.; Pan, L.; Xu, S.; et al. Vitamin D signaling maintains intestinal innate immunity and gut microbiota: Potential intervention for metabolic syndrome and NAFLD. Am. J. Physiol. Gastrointest. Liver Physiol. 2020, 318, 542-553. [CrossRef] [PubMed]

18. Schadt, H.S.; Gossl, R.; Sibel, N.; Aebischer, C.P. Quantification of vitamin D3 in feed, food, and pharmaceuticals using highperformance liquid chromatography/tandem mass spectrometry. J. AOAC Int. 2012, 95, 1487-1494. [CrossRef]

19. Sakomura, N.K.; Rostagno, H.S. Métodos de Pesquisa em Nutrição de Monogástricos, 2nd ed.; Funep: Jaboticabal, Brazil, $2016 ;$ p. 262.

20. Weber, G.M.; Witschi, A.-K.M.; Wenk, C.; Martens, H. Triennial Growth Symposium-Effects of dietary 25-hydroxycholecalciferol and cholecalciferol on blood vitamin $\mathrm{D}$ and mineral status, bone turnover, milk composition, and reproductive performance of sows. J. Anim. Sci. 2014, 92, 899-909. [CrossRef]

21. Seedor, J.G.; Quartuccio, H.A.; Thompson, D.D. The bisphosphonate alendronate (MK-217) inhibits bone loss due to ovariectomy in rats. J. Bone Miner. Res. 1991, 6, 339-346. [CrossRef]

22. Lee., J. Molecular Basis of Feed Efficiency in Meat-Type Chickens. Ph.D. Thesis, University of Georgia, Athens, GA, USA, 2012.

23. Livak, K.J.; Schmittgen, T.D. Analysis of Relative Gene Expression Data Using Real-Time Quantitative PCR and the $2-\Delta \Delta C T$ Method. Methods 2001, 25, 402-408. [CrossRef]

24. Salim, H.M.; Zaman, M.A.; Beg, M.A.H.; Khaleduzzaman, A.B.M. Effect of supplemental 25-hydroxycholecalciferol on live performance, bone development, and mineral utilization of broiler chickens fed low dietary Ca and P. EC Nutr. 2019, 14, 227-238.

25. Hutton, K.C.; Vaughn, M.A.; Litta, G.; Turner, B.J.; Starkey, J.D. Effect of vitamin D status improvement with 25hydroxycholecalciferol on skeletal muscle growth characteristics and satellite cell activity in broiler chickens. J. Anim. Sci. 2014, 92, 3291-3299. [CrossRef]

26. Whitehead, C.C.; McCormack, H.A.; McTeir, L.; Fleming, R.H. High vitamin $\mathrm{D}_{3}$ requirements in broilers for bone quality and prevention of tibial dyschondroplasia and interactions with dietary calcium, available phosphorus, and vitamin A. Br. Poult. Sci. 2004, 45, 425-436. [CrossRef] [PubMed]

27. Rao, S.V.R.; Raju, M.V.L.N.; Panda, A.K.; Sunder, G.S.; Sharma, R.P. Effect of High Concentrations of Cholecalciferol on Growth, Bone Mineralization, and Mineral Retention in Broiler Chicks Fed Suboptimal Concentrations of Calcium and Nonphytate Phosphorus. J. Appl. Poult. Res. 2006, 15, 493-501. [CrossRef]

28. Angel, R.; Saylor, W.W.; Mitchell, A.D.; Powers, W.; Applegate, T.J. Effect of dietary phosphorus, phytase, and 25hydroxycholecalciferol on broiler chicken bone mineralization, litter phosphorus, and processing yields. Poult. Sci. 2006, 85, 1200-1211. [CrossRef] [PubMed]

29. Colet, S.; Garcia, R.G.; Almeida Paz, I.C.L.; Caldara, F.R.; Borille, R.; Royer, A.F.B.; Nääs, I.A.; Sgavioli, S. Bone characteristics of broilers supplemented with vitamin D. Braz. J. Poult. Sci. 2015, 17, 325-332. [CrossRef]

30. Bozkurt, M.; Yalçin, S.; Koçer, B.; Tüzün, A.E.; Akşit, H.; Özkan, S.; Uygun, M.; Ege, G.; Güven, G.; Yildiz, O. Effects of enhancing vitamin D status by 25-hydroxycholecalciferol supplementation, alone or in combination with calcium and phosphorus, on sternum mineralization and breast meat quality in broilers. Br. Poult. Sci. 2017, 58, 452-461. [CrossRef] [PubMed] 
31. Sakkas, P.; Smith, S.; Hill, T.R.; Kyriazakis, I. A reassessment of the vitamin D requirements of modern broiler genotypes. Poult. Sci. 2019, 98, 330-340. [CrossRef]

32. Fritts, C.A.; Waldroup, P.W. Effect of Source and Level of Vitamin D on Live Performance and Bone Development in Growing Broilers. J. Appl. Poult. Res. 2003, 12, 45-52. [CrossRef]

33. Ovesen, L.; Brot, C.; Jakobsen, J. Food contents and biological activity of 25-hydroxyvitamin D: A vitamin D metabolite to be reckoned with? Ann. Nutr. Metab. 2003, 47, 107-113. [CrossRef]

34. Moriuchi, S.; Deluca, H.F. Metabolism of vitamin D3 in the chick embryo. Arch. Biochem. Biophys. 1974, 164, 165-171. [CrossRef]

35. Nechama, H.; Hoff, D.; Harrell, A.; Edelstein, S. The intestinal absorption of vitamin D and its metabolites. J. Mol. Med. 1977, 2, $416-422$.

36. Hassan-Smith, Z.K.; Jenkinson, C.; Smith, D.J.; Hernandez, I.; Morgan, S.A.; Crabtree, N.J.; Gittoes, N.J.; Keevil, B.G.; Stewart, P.M.; Hewison, M. 25-hydroxyvitamin D3 and 1,25-dihydroxyvitamin D3 exert distinct effects on human skeletal muscle function and gene expression. PLoS ONE 2017, 12, e0170665. [CrossRef] [PubMed]

37. Chen, X.; Zhang, Q.; Applegate, T.J. Impact of dietary branched chain amino acids concentration on broiler chicks during aflatoxicosis. Poult. Sci. 2016, 95, 1281-1289. [CrossRef] [PubMed] 